\title{
KARAKTERISTIK KIMIA KONJUGAT ISOLAT PROTEIN KEDELAI-LAKTOSA YANG BERPOTENSI DALAM PENURUNAN ALERGENISITAS
}

\author{
[Chemical Characteristics of Soy Protein Isolate-Lactose Conjugate \\ with Potential to Reduce Allergenicity]
}

\author{
Muhammad Hasriandy Asyhari ${ }^{1)}$, Nurheni Sri Palupi ${ }^{2,3) \star}$, dan Didah Nur Faridah ${ }^{2,3)}$ \\ ${ }^{1)}$ Program Studi Ilmu Pangan, Sekolah Pascasarjana, Institut Pertanian Bogor, Bogor \\ 2) Departemen Ilmu dan Teknologi Pangan, Fakultas Teknologi Pertanian, Institut Pertanian Bogor, Bogor \\ 3) Southeast Asian Food and Agricultural Science and Technology (SEAFAST) Center, Institut Pertanian Bogor, Bogor
}

Diterima 13 Januari 2018 / Disetujui 28 April 2018

\begin{abstract}
Soy protein isolate (SPI) is a product of soybeans possessing good functionality thus it is widely used as an ingredient in any formulation in food and beverage industries. Glycation is commonly done to improve protein functionality and reduce its allergenicity. This research aims to evaluate the influence of incubation time of SPI and lactose on the degree of glycation of SPI-lactose conjugates, free amino acid and lactose, and to determine the molecular weight and intensity of the protein band of the SPI-lactose conjugate. SPIs were obtained by $\mathrm{pH}$ adjustment. The glycation of SPI and lactose was undertaken at $\mathrm{pH}$ $9.5,95^{\circ} \mathrm{C}$ for $0,30,60$ and 90 minutes. The determination of the glycation degree of the SPI-lactose conjugate was carried out using several methods, i.e. TBA-based method, HPLC and Bradford analysis. The profiles of the protein molecular weight was analyzed using SDS-PAGE. The results revealed that longer incubation time induced a greater degree of glycation. The SDS-PAGE showed that the soybean sample had 13 protein bands with molecular weights ranging from 11.8 to $170.2 \mathrm{kDa}$. Glycation of the SPI with lactose at $95^{\circ} \mathrm{C}$ could remove or lower the intensity of protein bands with molecular weight of 66.6; 56.1 and $30.9 \mathrm{kDa}$, which were presumed to be the major allergens in soybean.
\end{abstract}

Keywords: degree of glycation, glycation, lactose, soy protein isolate

\begin{abstract}
ABSTRAK
Isolat protein kedelai (IPK) adalah salah satu produk dari kedelai yang memiliki sifat fungsional yang baik sehingga banyak digunakan oleh industri pangan sebagai bahan formulasi berbagai makanan dan minuman. Glikasi banyak dilakukan untuk meningkatkan fungsionalitas protein dan mengurangi alergenisitas. Penelitian ini bertujuan menganalisis pengaruh waktu inkubasi IPK dengan laktosa terhadap derajat glikasi berbasis konjugat IPK-laktosa, amino bebas, dan laktosa serta mengetahui bobot molekul dan intensitas pita protein konjugat IPK-laktosa. Isolat protein diperoleh dengan pengaturan pH. Glikasi IPK dengan laktosa dilakukan dalam kondisi $\mathrm{pH} 9,5$, suhu $95^{\circ} \mathrm{C}$ selama $0,30,60$, dan 90 menit. Penentuan derajat glikasi pada produk konjugat IPK-laktosa dilakukan menggunakan beberapa metode yakni diantaranya metode berbasiskan TBA, HPLC, dan Bradford. Profil bobot molekul protein dianalisis menggunakan elektroforesis SDS-PAGE. Hasil penelitian menunjukkan bahwa semakin lama waktu inkubasi maka semakin besar pula derajat glikasi yang dihasilkan. Hasil elektroforesis SDS-PAGE menunjukkan bahwa kacang kedelai memiliki 13 pita protein dengan bobot molekul antara 11,8 sampai dengan $170,2 \mathrm{kDa}$. Perlakuan glikasi dengan laktosa selama inkubasi pada suhu $95^{\circ} \mathrm{C}$ dapat menghilangkan ataupun menurunkan intensitas pita protein dengan bobot molekul 66,6; 56,1; dan 30,9 kDa yang diduga merupakan alergen utama pada kedelai.
\end{abstract}

Kata kunci: derajat glikasi, glikasi, isolat protein kedelai, laktosa

\section{PENDAHULUAN}

Kedelai merupakan salah satu jenis kacangkacangan yang memiliki kadar protein yang tinggi. Dalam industri pangan, kedelai banyak dimanfaatkan dalam bentuk produk intermediate seperti isolat

*Penulis Korespondensi:

Email: hnpalupi@yahoo.com protein kedelai (IPK). IPK mengandung $90 \%$ protein dengan komponen utama yaitu $\beta$-conglycinin (7S globulin) dan glisinin (11S globulin) (Li et al., 2016). Produk ini dapat digunakan sebagai ingredien pangan pada berbagai produk olahan seperti sosis, susu formula, nuget, dan sebagainya. Selain memiliki kadar protein yang tinggi, kedelai juga memiliki komponen bioaktif yang bermanfaat bagi kesehatan. Kedelai memiliki beberapa sifat fungsional seperti da- 
pat menurunkan kolesterol dan gula darah serta mengurangi risiko penyakit jantung. Salah satu faktor yang menyebabkan terjadinya peningkatan konsumsi kedelai adalah karena timbulnya kesadaran masyarakat terkait sifat fungsional pada kedelai. Disisi lain kedelai juga memiliki sifat alergenisitas yang dapat membatasi konsumsi bagi penderita alergi. Dalam menangangani masalah tersebut, proses pengolahan kedelai dapat menjadi faktor penting untuk mengurangi risiko alergi melalui modifikasi struktur protein kedelai menjadi pangan hipoalergenik.

Pengolahan seperti pemanasan, fermentasi enzimatik, perlakuan fisik seperti pemberian tekanan tinggi atau ekstruksi, maupun kombinasi dari pengolahan tersebut dapat mengurangi alergenisitas (Verhoeckx et al., 2015). Akan tetapi metodemetode tersebut juga memiliki banyak kekurangan. Misalnya hidrolisis enzimatik menyebabkan adanya fragmen peptida yang menimbulkan rasa pahit. Proses pengolahan yang melibatkan reaksi Maillard merupakan salah satu alternatif yang efisien dan aman apabila diterapkan sebagai solusi untuk mengurangi alergenisitas dari kacang kedelai. Pengolahan yang melibatkan reaksi Maillard ini dapat dilakukan dengan mengonjugasikan protein dengan gula pereduksi melalui ikatan kovalen membentuk produk protein terglikasi.

Pada beberapa penelitian diketahui bahwa glikasi dapat digunakan sebagai alternatif untuk meningkatkan fungsionalitas protein. Glikasi yang diinduksi oleh reaksi Maillard dapat meningkatkan kelarutan, stabilitas terhadap panas, emulsifikasi, daya buih, dan sifat pembentukan gel (de Oliveira et al., 2016) sekaligus mengurangi alergenisitas (van de Lagemaat et al., 2007). Akan tetapi jika kondisi reaksi tidak tepat maka tujuan tersebut tidak dapat terpenuhi. Banyak faktor yang mempengaruhi reaksi glikasi beberapa diantaranya yaitu suhu, aktivitas air, jenis gula pereduksi, $\mathrm{pH}$, dan waktu inkubasi atau lama penyimpanan (Patel et al., 2013). Derajat glikasi menjadi parameter penting untuk menilai keberhasilan glikasi. Penelitian van de Lagemaat et al. (2007) melaporkan bahwa glikasi IPK-FOS pada beberapa kondisi dapat meningkatkan derajat glikasi dan menurunkan antigenesitas dengan meningkatnya waktu inkubasi. Bu et al. (2015) yang juga melakukan penelitian glikasi glisinin dengan laktosa melaporkan bahwa terjadi penurunan grup amino bebas, peningkatan derajat glikasi, dan peningkatan waktu inkubasi dapat meningkatkan laju penghambatan antigenesitas glisinin. Glikasi antara protein dengan gula pereduksi akan mengubah struktur epitop sehingga mengurangi tingkat reaktivitas $\lg G$ dan IgE (Bielikowicz et al., 2010). Modifikasi antigenesitas kedelai berkaitan dengan kondisi reaksi dan derajat glikasi. Peningkatan derajat glikasi berkorelasi dengan perubahan struktur antigen pada protein kedelai sehingga dapat menurunkan alergenisitas.
Penelitian Bu et al. (2010) menunjukkan bahwa perubahan antigenesitas $\beta$-laktoglobulin yang terdapat pada whey protein isolate (WPI) sangat bergantung dari seberapa besar derajat glikasi yang dihasilkan melalui reaksi Maillard. Adanya peningkatan derajat glikasi akibat reaksi Maillard tersebut ternyata berkaitan dengan terjadinya perubahan antigenesitas pada $\beta$-laktoglobulin.

Laktosa merupakan salah satu jenis gula pereduksi yang banyak terdapat pada susu dan produk olahannya. Laktosa memiliki fungsi fisiologis yang baik seperti sumber energi untuk tubuh dan meningkatkan penyerapan mineral (kalsium, fosfor, dan magnesium). Meskipun kekhawatiran konsumen tentang intoleransi laktosa, industri pangan dan farmasi telah menemukan banyak aplikasi untuk laktosa, terutama dalam bentuk kristal (Carpin et al., 2016). Saat ini laktosa banyak digunakan oleh industri pangan sebagai ingredien, produk minuman (beverage) maupun produk permen (confectionary) karena mempunyai kemanisan yang rendah, dapat mengikat flavor dan aroma, dan meningkatkan umur simpan produk (Bu et al., 2015). Selain itu, laktosa juga biasa digunakan sebagai eksipien dan agen tablet di industri farmasi (Carpin et al., 2016). Laktosa lebih reaktif dibandingkan maltrodekstrin sehingga memiliki stabilitas panas yang baik dalam membentuk produk protein terglikasi (Liu dan Zhong 2015). Tujuan penelitian ini adalah menganalisis pengaruh waktu inkubasi IPK dengan laktosa terhadap derajat glikasi basis konjugat IPK-laktosa, amino bebas, dan laktosa serta mendapatkan profil bobot molekul dan menganalisis intensitas pita protein konjugat IPK-laktosa menggunakan elektroforesis SDS-PAGE. Dengan adanya profil dari produk konjugat IPK-laktosa tersebut maka dapat diketahui seberapa besar perubahan struktur protein yang terjadi selama proses glikasi. Perubahan struktur pada protein kedelai inilah yang dapat digunakan sebagai acuan untuk mengetahui adanya potensi penurunan alergenisitas pada IPK.

\section{BAHAN DAN METODE}

\section{Bahan}

Bahan yang digunakan dalam penelitian ini antara lain kedelai lokal varietas Detam-1 yang diperoleh dari Balai Penelitian Tanaman Aneka Kacang dan Umbi (Balitkabi) dan laktosa p.a (Difco, Detroit, USA).

\section{Isolasi protein}

Kacang kedelai digiling dan diayak dengan ayakan 60 mesh. Sebelum dilakukan isolasi protein, terlebih dahulu dilakukan analisis proksimat pada tepung kacang kedelai untuk mengetahui komposisi kimianya. Isolasi protein sampel diawali dengan 
penghilangan lemak (Liu et al., 2007). Sampel yang telah dihaluskan direndam dalam heksana (teknis) (rasio 1:5 w/v) selama 1 jam pada suhu kamar, kemudian disentrifus (Eppendorf Centrifuge 5810R, Hamburg, Germany) (8.000 g selama 15 menit pada suhu $\left.4^{\circ} \mathrm{C}\right)$. Supernatan yang diperoleh dibuang, sedangkan endapannya diekstraksi kembali sebanyak dua kali untuk menghilangkan kandungan lemak yang masih tersisa. Isolasi protein menggunakan metode pengaturan $\mathrm{pH}$ mengacu pada penelitian Speroni et al. (2010). Sampel bebas lemak dicampur dengan akuades (rasio 1:10 w/v), kemudian $\mathrm{pH}$ suspensi dinaikkan sampai 8 dengan menggunakan $\mathrm{NaOH} 1 \mathrm{~N}$ (Merck, Darmstadt, Germany), diaduk selama 90 menit pada suhu ruang dan disentrifus (10.000 g selama 30 menit pada suhu $4^{\circ} \mathrm{C}$ ). Nilai pH supernatan yang diperoleh diturunkan sampai 4,5 dengan menggunakan $\mathrm{HCl} 1 \mathrm{~N}$ (Merck, Darm-stadt, Germany), lalu disentrifus selama 20 menit. Supernatan yang diperoleh dibuang, sedangkan endapan proteinnya diambil dan dikeringkan dengan pengering beku (EYELA, FD-550, Tokyo Rikakikai Co.Ltd., Japan).

\section{Konjugasi IPK-laktosa}

Konjugasi dilakukan dalam formulasi sistem pangan cair berdasarkan penelitian van de Lagema at et al. (2007) dengan modifikasi. IPK dan laktosa dilarutkan dalam 0,5 M buffer karbonat-bikarbonat $(\mathrm{pH} 9,5)$ dengan rasio spesifik (IPK:laktosa $=4: 1$, rasio $\mathrm{w} / \mathrm{w})$. Campuran dituang ke dalam tabung bertutup rapat dan dipanaskan dalam water bath (GFL D-30938, Burgwedel, Germany) bersuhu $95^{\circ} \mathrm{C}$, dengan pengadukan konstan pada kecepatan 200 rpm. Sampel diinkubasi selama 0, 30, 60, dan 90 menit. Setiap kali pengambilan, sampel didinginkan segera dalam water bath berisi es, dilanjutkan dengan penyimpanan pada suhu $-20^{\circ} \mathrm{C}$. Sebagai kontrol, IPK tanpa laktosa diperlakukan dengan kondisi yang sama.

\section{Pengukuran derajat glikasi basis konjugat IPK- laktosa menggunakan metode TBA}

Analisis derajat glikasi mengacu pada metode Seri et al. (2017). Sebanyak $2 \mathrm{~mL}$ asam trikloroasetat 20\% (TCA) (Merck, Darmstadt, Germany) ditambahkan ke dalam $4 \mathrm{~mL}$ sampel, kemudian disentrifugasi selama 10 menit pada $3000 \mathrm{rpm}$. Satu $\mathrm{mL}$ buffer fosfat $0,01 \mathrm{M}(\mathrm{pH} 7,4)$ dan $0,5 \mathrm{~mL}$ asam oksalat 0,3 N (Merck, Darmstadt, Germany) ditambahkan ke dalam sedimen dan disimpan dalam penangas air selama 1 jam. Setelah dingin ditambahkan $0,5 \mathrm{~mL}$ TCA $40 \%$ ke dalam setiap sampel, kemudian disentrifugasi selama 10 menit pada $3000 \mathrm{rpm}$. Supernatan dipisahkan dan ditambahkan $0,5 \mathrm{~mL}$ asam tiobarbiturat 0,05 M (TBA) (Merck, Darmstadt, Germany) ke dalam $1 \mathrm{~mL}$ larutan supernatan tersebut, kemudian disimpan dalam penangas air dengan suhu $40^{\circ} \mathrm{C}$ selama 30 menit. Absorbansi sampel diukur pada $443 \mathrm{~nm}$ menggunakan spektrofotometer (UV-160, Shimadzu, Tokyo, Japan). Kontrol yang digunakan adalah sampel tanpa perlakuan glikasi. Pengukuran derajat glikasi (DG) konjugat IPK-laktosa dihitung dengan rumus berikut:

$$
\begin{aligned}
& \text { DG Konjugat IPK-Laktosa }(\%)= \\
& \frac{\text { absorbansi sampel - absorbansi kontrol }}{\text { absorbansi sampel }} \times 100 \%
\end{aligned}
$$

\section{Pengukuran derajat glikasi basis laktosa meng- gunakan HPLC}

Analisis konsentrasi laktosa sisa berdasarkan cara kerja Shen et al. (2012) menggunakan HPLC (1200 Series, Agilent Technologies, Inc., Santa Clara, CA, USA) yang dilengkapi dengan detektor refractive index. Preparasi sampel diawali dengan pengendapan protein (Xinmin et al., 2008). Sampel sebanyak $5 \mathrm{~mL}$ dipipet ke labu ukur $25 \mathrm{~mL}$. Selanjutnya ditambahkan larutan timbal asetat 20\% (Merck, Darmstadt, Germany) sebanyak $1,5 \mathrm{~mL}$, campuran larutan natrium oksalat 1,5\% (Merck, Darmstadt, Germany) dan natrium hidrogen fosfat 3,5\% (Merck, Darmstadt, Germany) sebanyak $1,5 \mathrm{~mL}$ dan ditambahkan akuades hingga tepat $25 \mathrm{~mL}$. Sampel itu kemudian dibiarkan selama 30 menit dan disaring dengan kertas saring. Sebelum diinjeksi ke HPLC, sampel dan larutan standar laktosa grade HPLC (Sigma Aldrich Chemie Gmbh., Germany) disaring melalui membran nilon Millipore $\mathrm{FH}(0,22 \mu \mathrm{m})$ (Sartorius Stedim Biotech. Co., USA). Selanjutnya kolom Aminex® HPX-87H (300 mm x 7,8 mm) (BIORAD, Hercules, CA, USA) dielusi pada suhu $35^{\circ} \mathrm{C}$ dengan fase gerak asetonitril 5\% (Merck, Darmstadt, Germany) dalam $\mathrm{H}_{2} \mathrm{SO}_{4} 5 \mathrm{mM}$ (Merck, Darmstadt, Germany) pada laju alir $1 \mathrm{~mL} / \mathrm{min}$. Kuantifikasi laktosa sisa menggunakan kurva kalibrasi dalam kisaran 100-1000 ppm. Pengukuran derajat glikasi (DG) basis laktosa dihitung dengan rumus berikut:

DG Basis Laktosa (\%) =

$\frac{\text { konsentrasi laktosa awal - konsentrasi laktosa sisa }}{\text { konsentrasi laktosa awal }} \times 100 \%$

\section{Pengukuran derajat glikasi basis gugus amino bebas menggunakan pengujian Bradford}

Sampel diambil sebanyak $100 \mu \mathrm{L}$ dan dimasukkan ke dalam tabung reaksi berukuran $1,2 \times 10 \mathrm{~cm}$, lalu ditambahkan $5 \mathrm{~mL}$ pereaksi Bradford (Bradford 1976). Larutan divorteks dan diukur menggunakan spektrofotometer (UV-160, Shimadzu Tokyo, Japan) pada panjang gelombang $595 \mathrm{~nm}$ setelah 5 menit. Kontrol yang digunakan adalah sampel tanpa perlakuan glikasi. Pengukuran derajat glikasi (DG) basis gugus amino bebas konjugat IPK-laktosa dihitung dengan rumus berikut: 
DG Basis Gugus Amino Bebas $(\%)=\frac{\mathrm{C} 0-\mathrm{C} 1}{\mathrm{C} 0} \times 100 \%$ dimana, C0 adalah konsentrasi amino bebas kontrol dan $\mathrm{C} 1$ adalah konsentrasi gugus amino bebas sampel.

\section{Analisis profil bobot molekul dengan elektro- foresis SDS-PAGE}

Elektroforesis SDS-PAGE berdasarkan Laemmli (1970) dilakukan dengan stacking gel 5\% dan separating gel $12 \%$ menggunakan perangkat SDSPAGE (BIO-RAD, Hercules, CA, USA). Sampel sebanyak $10 \mu \mathrm{L}$ ditambahkan $40 \mu \mathrm{L}$ buffer sampel yang mengandung natrium dodesil sulfat (SDS, deterjen anionik) (Merck, Darmstadt, Germany), basa tris pH 6,8 dan $\beta$-merkaptoetanol (Merck, Darmstadt, Germany), lalu dipanaskan selama 5 menit dalam suhu $100^{\circ} \mathrm{C}$. Sampel dinjeksikan ke dalam sumur dan pada salah satu sumur ditempatkan marker protein Spectra Multicolor Broad Range Protein Ladder dengan bobot molekul 10-260 kDa (Thermo Scientific, Waltham, MA, USA, 26634). Proses elektroforesis dilakukan selama 180 menit pada $70 \mathrm{~V}$ sampai migrasi dye tersisa sekitar $0,5 \mathrm{~cm}$ dari dasar. Setelah proses running selesai dilakukan pewarnaan gel menggunakan coomasie briliant blue G-250 (Merck, Darmstadt, Germany) kemudian dibilas dengan akuades. Larutan penghilang warna (destaining solution) ditambahkan sampai muncul pita berwarna biru pada gel. Bobot molekul dan intensitas pita protein pada gel dianalisis dengan software GelAnaly-zer 2010a. Prinsip pengukuran persentase intensitas pada software GelAnalyzer 2010a berdasarkan perbedaan intensitas warna pada pita protein. Semakin gelap pita protein maka semakin tinggi intensitas yang dihasilkan.

\section{Pengolahan data}

Data berupa karakteristik kimia dari obyek pengamatan dirancang menggunakan Rancangan Acak Lengkap (RAL) dengan 4 perlakuan waktu inkubasi (0; 30; 60; dan 90 menit) ditampilkan secara deskriptif menggunakan ANOVA (Analysis of Varian$c e$ ). Pengolahan data dilakukan dengan aplikasi Statistical Package for the Social Sciences (SPSS, ver.24) untuk membandingkan signifikansi pada tingkat kepercayaan 95 persen. Jika terdapat beda nyata dari data yang diperoleh, maka dilanjutkan dengan uji Duncan.

\section{HASIL DAN PEMBAHASAN}

\section{Karakteristik isolat protein kedelai}

Kedelai yang digunakan pada penelitian ini adalah kedelai varietas Detam-1 yang merupakan kedelai varietas unggul dari perkebunan Balitkabi Malang. Keunggulan kedelai ini yaitu memiliki kadar protein yang lebih tinggi dan kadar lemak yang lebih rendah dibanding varietas lainnya (Hidayat et al., 2010). Kandungan protein yang diperoleh cukup tinggi yaitu sebesar $47,28 \%$. Komposisi kimia hasil analisis proksimat tepung kacang kedelai varietas lokal Detam-1 selengkapnya disajikan pada Tabel 1.

Proses isolasi didahului oleh proses penghilangan lemak (defatisasi) agar lemak yang terdapat dalam kacang kedelai tidak mengganggu proses isolasi protein. Defatisasi dilakukan menggunakan heksana untuk memperoleh tepung kacang bebas lemak mengacu pada metode yang dikembangkan (Liu et al., 2007). Sampel kacang kedelai diisolasi proteinnya dengan menggunakan metode pengaturan $\mathrm{pH}$ melalui gabungan alkali dan isoelectric precipitation. Berdasarkan penelitian Wu et al. (2009) yang membandingkan beberapa cara presipitasi, isolasi protein dengan metode ini dapat menghasilkan kadar protein tertinggi dan memiliki kelarutan protein, kapasitas pembentuk buih, dan stabilitas protein yang terbaik dibandingkan isolasi protein dengan metode isoelectric precipitation, aqueous precipitation, dan isoelectric and alcohol precipitations. Rendemen IPK basis tepung kedelai dan kacang kedelai diperoleh dengan metode pengaturan $\mathrm{pH}$ adalah sebesar $13,54 \%$ dan $11,35 \%$ (Tabel 2). Kandungan protein yang diperoleh pada penelitian ini telah mencapai lebih dari $90 \%$ maka produk ini dapat dikategorikan sebagai isolat protein.

Tabel 1. Komposisi kimia tepung kedelai Detam-1

\begin{tabular}{lc}
\hline \multicolumn{1}{c}{ Parameter } & Konsentrasi \\
\hline Kadar air $(\%$ bb) & $4,33 \pm 0,04$ \\
Kadar abu $(\%$ bk) & $5,06 \pm 0,05$ \\
Kadar protein $(\%$ bk) & $47,28 \pm 0,53$ \\
Kadar lemak $(\%$ bk) & $18,65 \pm 0,04$ \\
Kadar karbohidrat $(\%$ bk) & $29,00 \pm 0,44$ \\
\hline
\end{tabular}

Tabel 2. Rendemen dan kadar protein IPK

\begin{tabular}{lc}
\hline \multicolumn{1}{c}{ Parameter } & Konsentrasi \\
\hline Rendemen IPK basis tepung (\%) & $13,54 \pm 2,13$ \\
Rendemen IPK basis kacang kedelai (\%) & $11,35 \pm 1,78$ \\
Kadar protein IPK (\% bk) & $92,86 \pm 0,33$ \\
\hline
\end{tabular}

\section{Derajat glikasi basis konjugat IPK-laktosa}

Glikasi terjadi melalui ikatan kovalen antara grup karbonil dari gula pereduksi dengan grup amino bebas dari protein untuk membentuk basa Schiff (Schiff base) dan penataan ulang Amadori (Amadori rearrangement). Derajat glikasi biasanya digunakan untuk mengevaluasi tingkat dari reaksi Maillard (Bu et al., 2015). Pengukuran derajat glikasi dapat dilakukan dengan metode TBA melalui prinsip hidrolisis protein terglikasi menggunakan asam oksalat pada suhu $100^{\circ} \mathrm{C}$ membentuk hidroksimetil furfural (HMF) yang dapat bereaksi dengan TBA membentuk gugus kromofor (Seri et al., 2017). TCA $20 \%$ berfungsi untuk mengendapkan protein sisa dan protein terglikasi sehingga laktosa sisa yang ter- 
dapat pada supernatan tidak ikut bereaksi. Selanjutnya TCA $40 \%$ akan mengendapkan protein sisa sehingga hanya HMF yang dapat bereaksi dengan TBA. Data derajat glikasi konjugat IPK-laktosa berbagai waktu inkubasi disajikan pada Gambar 1 . Derajat glikasi meningkat secara signifikan setelah inkubasi selama 60 menit yaitu sebesar $37,28 \%$. Setelah menit ke-60 maka kenaikan derajat glikasi berlangsung tidak signifikan.

Peningkatan derajat glikasi diketahui berkorelasi dengan penurunan alergenisitas. Hal ini dibuktikan oleh penelitian Suseno et al. (2016) yang melakukan glikasi menggunakan FOS pada IPK GMO dan Non-GMO dengan pemanasan pada suhu $95^{\circ} \mathrm{C}$ selama 60 menit pada perlakuan rasio $1: 4$. Pada penelitian tersebut mampu dihasilkan derajat glikasi sebesar $56,82 \%$ pada IPK Non-GMO dan $51,42 \%$ pada IPK GMO dengan penurunan alergenitas sebesar $92,15 \%$ pada kedelai GMO sedangkan pada kedelai Non-GMO sebesar $82,02 \%$.

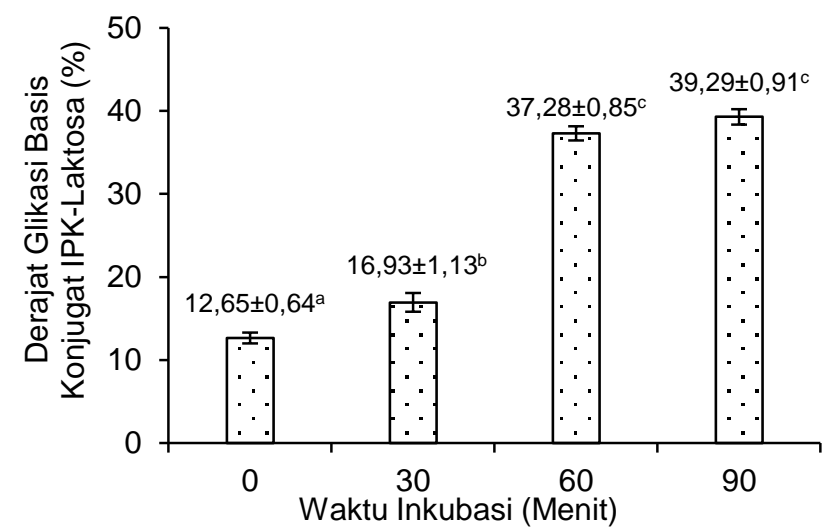

Gambar 1. Derajat glikasi basis konjugat IPK Laktosa pada berbagai waktu inkubasi. Angka-angka yang diikuti oleh huruf yang berbeda menunjukkan perbedaan nyata pada $(P<0,05)$

\section{Derajat glikasi basis amino bebas}

Analisis derajat glikasi basis amino bebas menggunakan pengujian Bradford disajikan pada (Gambar 2). Prinsip pengujian Bradford adalah berdasarkan interaksi elektrostatik antara residu asam amino basa (terutama arginin, lisin, dan histidin) dengan grup sulfonat dari coomasie briliant blue G250 (CBB) (Brady dan Macnaughtan, 2015). Perhitungan derajat glikasi basis amino bebas ini dilakukan berdasarkan selisih antara konsentrasi amino bebas kontrol dengan konsentrasi amino bebas pada produk konjugat IPK selama inkubasi. Semakin besar penurunan konsentrasi amino bebas pada produk konjugat IPK dibandingkan dengan kontrol maka semakin besar pula derajat glikasi yang dihasilkan. Berdasarkan analisis derajat glikasi pada Gambar 2 diketahui bahwa persentase derajat glikasi basis amino bebas mengalami peningkatan secara signifikan setelah inkubasi selama 60 menit yaitu sebesar $28,23 \%$. Dari data yang diperoleh dapat diketahui bahwa peningkatan waktu inkubasi berbanding lurus dengan derajat glikasi. Hal ini sejalan dengan penelitian $\mathrm{Bu}$ et al. (2015) terkait konjugasi glisinin dengan laktosa (rasio 4:1) yang menunjukkan adanya peningkatan derajat glikasi basis grup amino bebas dari $14,97 \%$ menjadi $46,68 \%$ pada inkubasi selama 48 jam. Apabila dibandingkan dengan penelitian tersebut maka penelitian ini berlangsung lebih efektif karena peningkatan derajat glikasi terjadi dari $15,81 \%$ menjadi $28,23 \%$ hanya dengan waktu inkubasi selama 1 jam.

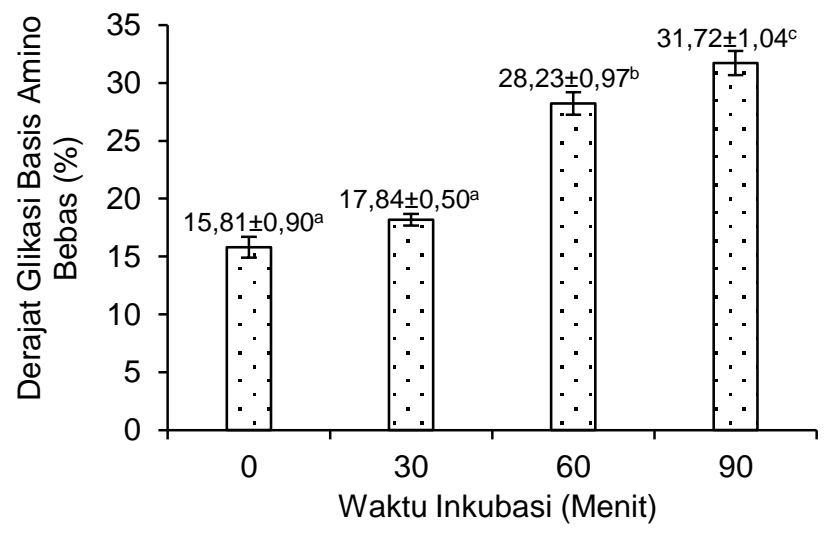

Gambar 2. Derajat glikasi basis amino bebas konjugat IPK-laktosa pada berbagai waktu inkubasi. Angka-angka yang diikuti oleh huruf yang berbeda menunjukkan perbedaan nyata pada $(P<0,05)$

Penurunan konsentrasi amino bebas pada sampel IPK selama inkubasi dapat terjadi karena sebagian besar grup amino bebas (khususnya lisin) pada protein kedelai telah berikatan dengan laktosa. Pada permulaan reaksi glikasi, grup amino bebas yang tidak terlindungi pada permukaan molekul protein akan cenderung untuk memulai reaksi dibandingkan grup amino bebas yang terlindungi (masked) pada bagian dalam protein. Reaksi pada grup amino bebas bagian dalam molekul protein terjadi ketika struktur protein berubah ketika dipanaskan. Hal ini sejalan dengan penelitian van de Lagemaat et al. (2007) yang melakukan glikasi pada IPK-FOS pada suhu $95^{\circ} \mathrm{C}$ dimana terjadi penurunan grup amino bebas sebanyak 30\% setelah inkubasi selama 60 menit. Penelitian Bu et al. (2010) menunjukkan glikasi WPI-glukosa (rasio 4:1) selama 72 jam pada suhu $60^{\circ} \mathrm{C}$ dapat menurunkan grup amino bebas sebesar $80 \%$. Pada awal reaksi glikasi, $\varepsilon$-grup amino dari lisin masih tersedia dalam jumlah yang sangat banyak. Namun selama reaksi glikasi berlangsung maka secara bertahap residu lisin tersebut akan semakin berkurang dikarenakan berikatan dengan gula pereduksi. Hal ini akan terus berlangsung 
hingga mencapai titik tertentu, dimana residu lisin tersebut telah habis karena berikatan dengan gula pereduksi sehingga reaksi glikasi akan berhenti (van de Lagemaat et al., 2007). Penurunan kadar amino bebas konjugat IPK-laktosa mengindikasikan terjadinya reaksi Maillard antara grup amino bebas protein dengan laktosa yang juga meningkatkan intensitas warna. Peningkatan warna coklat dapat menjadi indikasi reaksi glikasi semakin tinggi (Bu et al., 2010).

\section{Derajat glikasi basis laktosa}

Derajat glikasi basis laktosa ditentukan melalui perbandingan antara konsentrasi laktosa awal dengan konsentrasi laktosa sisa setelah dilakukan proses glikasi. Berdasarkan Gambar 3 dapat terlihat dengan meningkatnya waktu inkubasi menunjukkan peningkatan derajat glikasi. Hasil kromatogram HP LC diketahui laktosa memiliki waktu retensi menit 4,67-4,71. Pada menit ke-90, derajat glikasi basis laktosa sudah mencapai $92,52 \%$ Tingginya hasil derajat glikasi ini dapat disebabkan dua hal yaitu laktosa berikatan dengan IPK maupun terjadi isomerisasi pada laktosa. Kondisi suhu tinggi dan $\mathrm{pH}$ basa memungkinkan laktosa mengalami isomerisasi menjadi laktulosa. Pengukuran derajat glikasi basis laktosa didasarkan atas selisih kadar laktosa awal dengan kadar laktosa sisa diakhir reaksi glikasi. Derajat glikasi basis laktosa tersebut tidak bisa dijadikan acuan karena tidak semua laktosa terglikasi dengan IPK, namun terdapat juga sebagian laktosa yang sudah mengalami isomerisasi menjadi laktulosa. Hal inilah yang menyebabkan hasil derajat glikasi basis laktosa lebih tinggi dibandingkan dengan hasil derajat glikasi basis konjugat IPK-laktosa dan amino bebas.

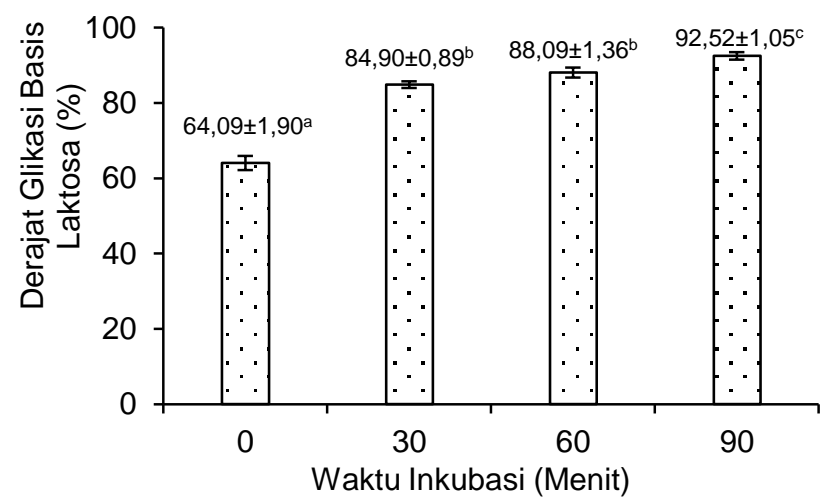

Gambar 3. Derajat glikasi basis laktosa konjugat IPK-Laktosa pada berbagai waktu inkubasi. angka-angka yang diikuti oleh huruf yang berbeda menunjukkan perbedaan nyata pada $(P<0,05)$.

Penelitian Hashemi dan Ashtiani (2010) menunjukkan terjadi peningkatan isomerisasi laktosa menjadi laktulosa pada $\mathrm{pH}$ 10; 11 dan 12 dengan pemanasan pada suhu $50 ; 60$ dan $70^{\circ} \mathrm{C}$ selama 300 menit. Pemanasan berlanjut akan meningkatkan pembentukan galaktosa dan glukosa serta menurunkan kadar laktosa (Aissa dan Aïder, 2013).

Hasil pengukuran derajat glikasi dengan ketiga metode yang dilakukan menghasilkan pola yang sama yaitu peningkatan waktu inkubasi berbanding lurus dengan derajat glikasi. Meskipun demikian, hasil derajat glikasi basis laktosa lebih tinggi dibandingkan dengan hasil derajat glikasi basis konjugat IPKlaktosa dan amino bebas disebabkan adanya isomerisasi pada laktosa. Derajat glikasi berlangsung secara signifikan setelah inkubasi selama 60 menit dan setelah itu peningkatannya cenderung tidak signifikan. Ketersediaan laktosa yang sudah menipis sehingga jumlah gula pereduksi yang digunakan untuk bereaksi dengan residu lisin semakin sedikit.

\section{Profil bobot molekul protein berdasarkan elek- troforesis SDS-PAGE}

Hasil elektroforesis SDS-PAGE konjugat IPK dengan laktosa disajikan pada Gambar 4. Sebanyak 13 pita protein terdeteksi setelah dianalisis dengan software GelAnalyzer 2010a untuk IPK dengan bobot molekul 11,8-170,2 kDa dengan beberapa pita protein yang cukup tebal yaitu 66,$6 ; 56,1$; dan 30,9 $\mathrm{kDa}$. Suseno et al. (2016) melaporkan bahwa hasil elektroforesis SDS-PAGE kacang kedelai GMO dan kedelai non-GMO masing-masing memiliki 11 pita protein dan 9 pita protein dengan bobot molekul antara 4,8-145,8 kDa. Penelitian lainnya Palupi et al. (2015) mendapatkan 8 pita protein dengan bobot molekul antara 9,6-114,7 kDa pada kedelai varietas Grobogan, Astuti et al. (2016) mendapatkan 7 pita protein pada kedelai yang dibeli dari pasar dengan bobot molekul 20-83,7 kDa, dan Kusumasari (2017) mendapatkan 12 pita protein dengan bobot molekul 21,2-95,2 kDa pada isolat protein kedelai komersial. Perbedaan varietas dan penanganan pada sampel kedelai menyebabkan hasil elektroforesis yang berbeda-beda.

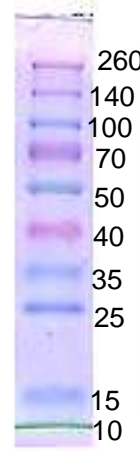

Marker

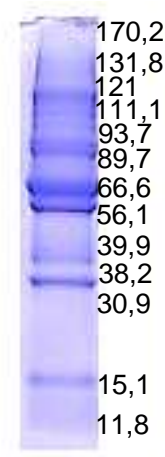

IPK

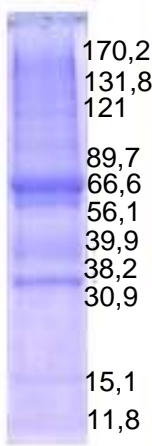

Inkubasi 30 Menit

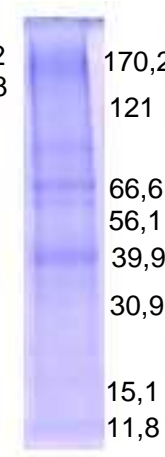

Inkubasi 60 Menit

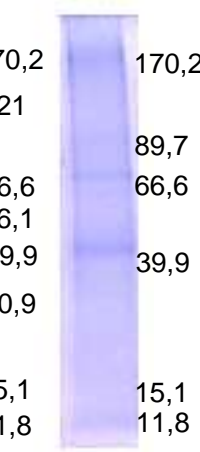

Inkubasi 90 Menit
Gambar 4. Profil bobot molekul protein IPK dan konjugat IPK-laktosa pada berbagai waktu inkubasi 
Terdapat perubahan profil bobot molekul konjugat IPK-laktosa dibandingkan dengan IPK sebelum perlakuan glikasi. Perlakuan glikasi dengan laktosa selama 30,60 , dan 90 menit pada suhu $95^{\circ} \mathrm{C}$ menyebabkan beberapa pita protein menghilang jika dibandingkan dengan kontrol. Pita protein yang menghilang pada perlakuan inkubasi 30 menit yaitu 111,1; 93,7; dan 38,2 kDa, sedangkan perlakuan inkubasi 60 menit menghilangkan pita protein 131,8; 111,1; 93,7; dan 38,2 kDa. Perlakuan inkubasi 90 menit menghilangkan 7 pita protein dengan bobot molekul 131,$8 ; 121 ; 111,1 ; 93,7 ; 56,1 ; 38,2$ dan $30,9 \mathrm{kDa}$.

Selain itu, semakin lama proses glikasi maka dapat menurunkan ketebalan pita protein yang menunjukkan konsentrasi protein tersebut. Van de Lagemaat et al. (2007) melaporkan hasil elektroforesis SDS-PAGE glikasi antara IPK dengan FOS (rasio 1:74) dengan waktu inkubasi 60 menit hanya memiliki dua pita protein yaitu 45 dan $66 \mathrm{kDa}$. Hasil tersebut menunjukkan bahwa perlakuan glikasi menyebabkan sebagian besar komponen protein dari kedelai telah bereaksi dengan FOS. Pada umumnya protein alergen pada kedelai berkisar antara 7-70 $\mathrm{kDa}$. Protein alergen yang dominan pada kedelai yaitu Gly m Bd 30K atau P34, Gly m Bd 28K, dan Gly $\mathrm{m}$ Bd 60K (Ogawa et al., 2000). Berdasarkan penelitian Amnuaycheewa dan de Mejia (2010), pita protein dengan bobot molekul 66,6 kDa diperkirakan sebagai protein alergen mayor Gly $\mathrm{m} \mathrm{Bd} 60 \mathrm{~K}$ yang merupakan subunit $\alpha$ dari $\beta$-conglycinin, pita protein dengan bobot molekul 56,1 kDa jenis glisinin (7S)globulin dan 30,9 kDa jenis Gly m Bd $30 \mathrm{~K}$ atau P34. Wilson et al. (2005) menyebutkan bahwa Gly $\mathrm{m} \mathrm{Bd}$ $30 \mathrm{~K}$ atau P34 diklasifikasikan sebagai alergen imunodominan pada kedelai. Gly $\mathrm{m} \mathrm{Bd} 30 \mathrm{~K}$ dapat berikatan dengan lebih dari $65 \%$ penderita alergi kacang kedelai. Bobot molekul yang terdeteksi pada bobot molekul 10-70 kDa disajikan pada Tabel 3 dibawah ini.

Intensitas pita protein IPK dan konjugat IPKlaktosa waktu inkubasi 30,60, dan 90 menit setelah dianalisis dengan software GelAnalyzer 2010a ditunjukkan pada Gambar 5. Pita protein yang cukup tebal pada IPK yaitu 66,6; 56,1; dan 30,9 kDa ditandai dengan arah panah. Peningkatan waktu inkubasi dapat menurunkan intensitas pita protein yang cukup tebal tersebut bahkan dapat menghilangkan pita protein 56,1 dan 30,9 kDa pada inkubasi selama 90 menit dengan suhu $95^{\circ} \mathrm{C}$. IPK terdiri dari 13 pita protein dengan intensitas berbeda-beda. Intensitas terbesar IPK terdapat pada protein Gly $\mathrm{m} \mathrm{Bd} 60 \mathrm{~K}$ dengan BM 66,6 kDa sebesar 21,92\%. Konjugat IPKlaktosa inkubasi 30 menit juga memperlihatkan intensitas terbesar pada BM 66,6 kDa sebesar $23,74 \%$. Hal ini menunjukkan bahwa pada waktu inkubasi tersebut masih didominasi oleh protein yang diduga merupakan protein alergen mayor Gly $\mathrm{m} \mathrm{Bd}$ 60K. Pada waktu inkubasi 60 dan 90 menit, intensi- tas terbesar pada $\mathrm{BM} 170,2 \mathrm{kDa}$ dengan nilai masing-masing $23,59 \%$ dan $22,39 \%$. Dari hasil tersebut menunjukkan bahwa glikasi dapat meningkatkan bobot molekul protein dan menurunkan intensitas protein yang diduga alergen mayor pada kedelai.

Tabel 3. Bobot molekul IPK dan konjugat IPK laktosa pada berbagai waktu inkubasi

\begin{tabular}{|c|c|c|c|c|c|}
\hline \multirow[b]{2}{*}{ No. } & \multicolumn{4}{|c|}{ Bobot Molekul (kDa) } & \multirow[b]{2}{*}{$\begin{array}{l}\text { Dugaan } \\
\text { Protein* }\end{array}$} \\
\hline & IPK & $\begin{array}{c}\text { Inkubasi } \\
30 \\
\text { menit }\end{array}$ & $\begin{array}{c}\text { Inkubasi } \\
60 \\
\text { menit }\end{array}$ & $\begin{array}{c}\text { Inkubasi } \\
90 \\
\text { menit }\end{array}$ & \\
\hline 1 & 66,6 & 66,6 & 66,6 & 66,6 & $\begin{array}{c}\text { Gly } \mathrm{m} \mathrm{Bd} \\
60 \mathrm{~K}\end{array}$ \\
\hline 2 & 56,1 & 56,1 & 56,1 & - & $\begin{array}{c}\text { 7S- } \\
\text { globulin }\end{array}$ \\
\hline 3 & 39,9 & 39,9 & 39,9 & 39,9 & $\begin{array}{l}\text { 11S- } \\
\text { globulin }\end{array}$ \\
\hline 4 & 38,2 & - & - & - & $\begin{array}{c}\text { 7S- } \\
\text { globulin }\end{array}$ \\
\hline 5 & 30,9 & 30,9 & 30,9 & - & $\begin{array}{c}\text { Gly m Bd } \\
30 \text { K atau } \\
\text { P34 }\end{array}$ \\
\hline 6 & 15,1 & 15,1 & 15,1 & 15,1 & $\begin{array}{l}\text { Gly m3, } \\
\text { profilin }\end{array}$ \\
\hline 7 & 11,8 & 11,8 & 11,8 & 11,8 & $\begin{array}{c}\text { Methionine } \\
\text { rich } \\
\text { protein }\end{array}$ \\
\hline
\end{tabular}

Sumber: Amnuaycheewa dan de Mejia (2010)

\section{KESIMPULAN}

Peningkatan waktu inkubasi pada suhu $95^{\circ} \mathrm{C}$ berkorelasi dengan peningkatan derajat glikasi. Semakin lama waktu inkubasi maka semakin besar pula derajat glikasi yang terbentuk. Peningkatan derajat glikasi berlangsung signifikan selama 60 menit waktu inkubasi. Profil bobot molekul IPK berkisar antara 11,8-170,2 kDa. Perlakuan glikasi dengan laktosa selama 30, 60, dan 90 menit pada suhu $95^{\circ} \mathrm{C}$ mampu menghilangkan ataupun menurunkan intensitas pita protein terutama pada bobot molekul 66,$6 ; 56,1$; dan $30,9 \mathrm{kDa}$. Hal ini menunjukkan telah terjadi perubahan struktur protein yang diduga sebagai alergen mayor pada kedelai. Oleh karena adanya perubahan struktur pada protein tersebut maka perlakuan glikasi memiliki potensi dalam menurunkan alergenisitas pada IPK. Untuk mendukung hasil penelitian ini, perlu dilakukan uji alergenisitas yang lebih spesifik dengan menggunakan antibodi.

\section{UCAPAN TERIMA KASIH}

Ucapan terima kasih disampaikan kepada Direktorat Jenderal Penguatan Riset dan Pengembangan, Kementerian Riset, Teknologi dan Pendidikan Tinggi yang telah membiayai penelitian ini melalui Program Penelitian Dasar Unggulan Perguruan Tinggi (PDUPT) tahun anggaran 2018 nomor: 1772/IT3.11/PN/2018. 

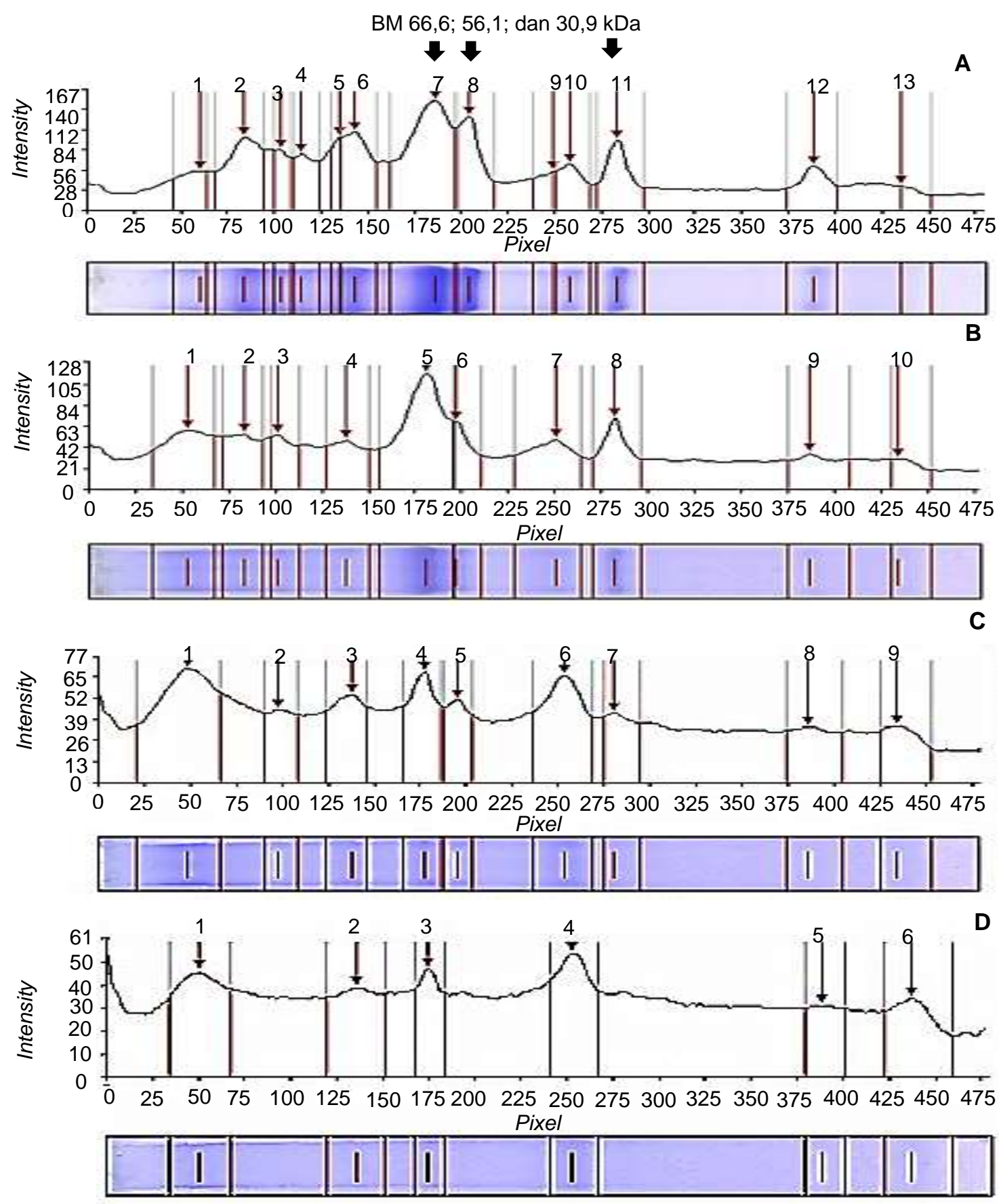

Keterangan: $(A)=$ IPK; $(B)=$ Inkubasi 30 menit; $(C)=$ Inkubasi 60 menit; (D) Inkubasi 90 menit setelah dianalisis dengan software GelAnalyzer 2010a

Gambar 5. Intensitas pita protein IPK dan konjugat IPK-laktosa pada berbagai waktu inkubasi

\section{DAFTAR PUSTAKA}

Aissa AA, Aïder M. 2013. Lactose isomerization into lactulose in an electro-activation reactor and high-performance liquid chromatography (HP LC) monitoring of the process. J Food Eng 119: 115-124. DOI: 10.1016/j.jfoodeng.2013.05.011.
Amnuaycheewa P, de Mejia EG. 2010. Purification, characterisation, and quantification of the soy allergen profilin (Gly $\mathrm{m} 3$ ) in soy products. Food Chem 119: 1671-1680. DOI: 10.1016/j.food chem.2009.09.034.

Astuti RM, Palupi NS, Zakaria FR. 2016. Allergic reactivity of bambara groundnut (Vigna sub- 
terranea) proteins. Food Agr Immunol 27: 535546. DOI: 10.1080/09540105.2015.1129601.

Bielikowicz K, Wojtacha P, Kostyra E, Iwan M, Jarmołowska B, Kostyra H. 2010. Influence of glycation of wheat albumins and globulins on their immunoreactivity and physicochemical properties. J Food Nutr Sci 60: 335-340.

Bradford MM. 1976. A rapid and sensitive method for the quantitation of microgram quantities of protein utilizing the principle of protein-dye binding. Anal Biochem 72: 248-254. DOI: 10. 1016/0003-2697(76)90527-3.

Brady PN, Macnaughtan MA. 2015. Evaluation of colorimetric assays for analyzing reductively methylated proteins: Biases and mechanistic insights. Anal Biochem 491: 43-51. DOI: 10.10 16/j.ab.2015.08.027.

Bu G, Luo Y, Lu J, Zhang Y. 2010. Reduced antigenicity of $\beta$-lactoglobulin by conjugation with glucose through controlled Maillard reaction conditions. Food Agr Immunol 21: 143156. DOI: $10.1080 / 09540100903452122$.

Bu G, Zhang N, Chen F. 2015. The influence of glycosylation on the antigenicity, allergenicity, and structural properties of 11S-lactose conjugates. Food Res Int 76: 511-517. DOI: 10.1016/j.food res.2015.08.004.

Carpin M, Bertelsen H, Bech JK, Jeantet R, Risbo J, Schuck P. 2016. Caking of lactose: A critical review. Trends Food Sci Technol 53: 1-12. DOI: 10.1016/j.tifs.2016.04.002.

Drapala KP, Auty MAE, Mulvihill DM, O'Mahony JA. 2015. Improving thermal stability of hydrolysed whey protein-based infant formula emulsions by protein-carbohydrate conjugation. Food Res Int 88: 1-10. DOI: 10.1016/j. foodres.2016.01.028.

Hashemi SA, Ashtiani FZ. 2010. The isomerization kinetics of lactose to lactulose in the presence of sodium hydroxide at constant and variable pH. Food Bioprod Process 88: 181-187. DOI: 10.1016/j.fbp.2009.11.001.

Hidayat M, Kurnia D, Sujatno M, Sutadipura N, Setiawan. 2010. Perbandingan kandungan makronutrisi dan isoflavon dari kedelai detam 1 dan wilis serta potensinya dalam menurunkan berat badan. J Ilmu-ilmu Hayati Fis 12: 5-13.

Kusumasari S. 2017. Validasi Metode Deteksi Alergen Kedelai dan Aplikasinya dalam Pengembangan Isolat Protein Kedelai dan Susu Kedelai Hipoalergenik [Tesis]. Bogor: Fakultas teknologi Pertanian, Institut Pertanian Bogor.
Laemmli UK. 1970. Cleavage of structural proteins during the assembly of the head of bacteriophage T4. Nature 227: 680-685. DOI: 10.10 38/227680a0.

van de Lagemaat J, Manuel Silván J, Javier Moreno F, Olano A, Dolores del Castillo M. 2007. In vitro glycation and antigenicity of soy proteins. Food Res Int 40: 153-160. DOI: 10.1016/j.food res.2006.09.006.

Li W, Zhao H, He Z, Zeng M, Qin F, Chen J. 2016. Modification of soy protein hydrolysates by Maillard reaction: Effects of carbohydrate chain length on structural and interfacial properties. Colloid Surface B 138: 70-77. DOI: 10.1016/ j.colsurfb.2015.11.038.

Liu C, Wang H, Cui Z, He X, Wang X. 2007. Optimization of extraction and isolation for $11 \mathrm{~S}$ and $7 \mathrm{~S}$ globulins of soybean seed storage protein. Food Chem 102: 1310-1316. DOI: 10.1016/j. foodchem.2006.07.017.

Liu G, Zhong Q. 2015. High temperature-short time glycation to improve heat stability of whey protein and reduce color formation. Food Hydrocolloid 44: 453-460. DOI: 10.1016/j.foodhyd.20 14.10.006.

Ogawa T, Samoto M, Takahashi K. 2000. Soybean allergens and hypoallergenic soybean products. J Nutr Sci Vitaminol 46: 271-279. DOI: 10.3177/jnsv.46.271.

de Oliveira FC, Coimbra JS dos R, de Oliveira EB, Zuñiga ADG, Rojas EEG. 2016. Food proteinpolysaccharide conjugates obtained via the maillard reaction-a review. Crit Rev Food Sci 56: 1108-1125. DOI: 10.1080/10408398.2012. 755669.

Palupi NS, Sitorus SR, Kusnandar F. 2015. Perubahan alergenisitas protein kacang kedelai dan kacang bogor akibat pengolahan dengan panas. J Teknol Industri Pangan 26: 222-231. DOI: 10.6066/jip.2015.26.2.222.

Patel KN, Modi RB, Patel HG, Aparnathi KD. 2013. Browning, its chemistry and implications in dairy products - a review. Indo-Am J Agric Vet Sci 1: 1-12.

Seri A, Khorsand M, Rezaei Z, Hamedi A, Takhshid MA. 2017. Inhibitory effect of bunium persicum hydroalcoholic extract on glucose-induced albumin glycation, oxidation, and aggregation in vitro. Iran J Med Sci 42: 369-376. 
Shen Q, Yang R, Hua X, Ye F, Wang H, Zhao W, Wang K. 2012. Enzymatic synthesis and identification of oligosaccharides obtained by transgalactosylation of lactose in the presence of fructose using $\beta$-galactosidase from Kluy-veromyces lactis. Food Chem 135: 1547-1554. DOI: 10.1016/j.foodchem.2012.05.115.

Speroni F, Milesi V, Añón MC. 2010. Interactions between isoflavones and soybean proteins: Applications in soybean-protein isolate production. LWT-Food Sci Technol 43: 1265-1270. DOI: 10.1016/j.Iwt.2010.03.011.

Suseno R, Palupi NS, Prangdimurti E. 2016. Alergenisitas sistem glikasi isolat protein kedelaifruktooligosakarida. Agritech 36: 450-458. DOI: 10.22146/agritech.16770.

Verhoeckx KCM, Vissers YM, Baumert JL, Faludi R, Feys M, Flanagan S, Herouet-Guicheney $C$, Holzhauser T, Shimojo R, van der Bolt N,
Wichers H, Kimber I. 2015. Food processing and allergenicity. Food Chem Toxicol 80: 223240. DOI: 10.1016/j.fct.2015.03.005.

Wilson S, Blaschek K, Mejia EG De. 2005. Allergenic proteins in soybean: processing and reduction of P34 allergenicity. Nutr 63: 47-58. DOI: 10.1301/nr.2005.feb.47.

Wu H, Wang Q, Ma T, Ren J. 2009. Comparative studies on the functional properties of various protein concentrate preparations of peanut protein. Food Res Int 42: 343-348. DOI: 10. 1016/j.foodres.2008.12.006.

Xinmin W, Ruili Z, Zhihua L, Yuanhong W, Tingfu J. 2008. Determination of glucosamine and lactose in milk-based formulae by high-performance liquid chromatography. J Food Compos Anal 21: 255-258. DOI: 10.1016/j.jfca.2007.10. 006. 